直腸肛門癌に括けるリンパ節跳踓転移の検討

\begin{tabular}{|c|c|c|c|c|c|c|c|}
\hline \multicolumn{8}{|c|}{ 鹿児島大学第 1 外科 } \\
\hline 山田 & 一隆 & 石沢 & 隆 & 春山 & 勝郎 & 四本 & 紘一 \\
\hline 平島 & 忠久 & 藤原 & 章 & 有本 & 之嗣 & 桂 & 禎紀 \\
\hline 鮫島 & 隆志 & 島津 & 久明 & & & & \\
\hline
\end{tabular}

\title{
A STUDY ON JUMPING METASTASES OF LYMPH NODES IN ANORECTAL CANCER
}

\section{Kazutaka YAMADA, Takashi ISHIZAWA, Katsuro HARUYAMA, Kouiti YOTSUMOTO, Tadahisa HIRASHIMA, Akira FUJIWARA, Yukitsugu ARIMOTO, Yoshinori KATSURA, Takashi SAMESHIMA and Hisaaki SHIMAZU}

First Department of surgery, Kagoshima University School of Medicine

\begin{abstract}
過去14年間に扔いて教室で切除を行った直腸肛門癌は172例であり，リンパ節転移陽性症例は89例 （52\%）であった。これらのうち，リンパ節跳躍転移は Raで 3 例， Rbで 1 例， P で 2 例に認められ， リンパ節転移症例の $7 \%$ (6/89例) を占めていた。リンパ節跳踓転移形式として, 第 1 群リンパ節を 素通りして直接第 2 群リンパ節へ跳躍する形式が 5 例に認められた。 また, 腫瘍下縁が歯状線上方 2.5 $\mathrm{cm}$ にあるにもかかわらず, 鼠径リンパ節へ転移が認められた直腸癌症例に打いて, 第 1 群リンパ節か ら第 4 群リンパ節へ跳躍する形式が認められた。これらの症例における, リンパ節転移の跳踓経路に ついて考察した.
\end{abstract}

索引用語：直腸肛門癌，リンバ節跳躍転移，臼径リンパ節転移

\section{はじめに}

大腸癌の進展形式として, ッンパ行性, 血行性, 局 所他臓器浸潤㧍よび腹膜播種の 4 つ重要な経路の存在 が判明しているが, なかでももっともしばしばみられ るのはリンパ節転移である。 わが国の「大腸癌取扱い 規約」)では大腸癌のリンパ節転移の程度が, 癌占居部 位ごとに血管系に沿って第 1 群から第 4 群までに分類 されている，乙かし，取扱い規約による順序を踏まな い転移形式，いわゆる跳躍転移が大腸癌においても存 在することが知られている. 大腸癌のリンパ節転移形 式のなかでも，直腸癌では腹膜反転部を境として，上 直腸動脈・下腸間膜動脈系の上方向に向からもの, 中 および下直腸動脈から内腸骨動脈系の水平方向(側方, 前方, 後方) に向からあの, さらに曾状線 (以下 DL)

$<1987$ 年 2 月18日受理 $>$ 別刷請求先：山田 一隆 干890 鹿児島市宇宿町1208-1 鹿児島大学医学部 第 1 外科
近辺のものでは下方向 (鼠径部) に向からものなどが あり, 結腸癌に比べ複雑な転移様式をとることが知ら れている2．そこで今回, 当教室で切除を行った直腸肛 門癌症例におけるリンパ節転移のらち，とくに跳躍転 移例の臨床病理学的所見拉よびリンパ節転移形式につ いて検討を行った。また腫瘍下縁が DLの上方にある 直腸癌でも鼠径リンパ節に跳踓転移を起こした症例を 経験したので，このリンパ節転移形式についても検討 した.

\section{I. 対象および方法}

昭和 47 年 12 月より昭和 60 年 12 月までに当教室で切除 を行った直晹癌および肛門癌172例を対象とした。多発 癌および大腸腺腫症は除外した. 占居部位の内訳は Rs 18例, Ra 18例， RaRb 26例, Rb 73例， RbP 25例， $\mathrm{P}$ 12例であり，これらの症例の全摘出リンハ節を「大腸 癌取扱い規約 ${ }^{1}$ に従い分頑し, 最大径の割面の切片に ついて Hematoxylin-Eosin 染色を行い病理組織学的 
に検索した。なおリンパ節跳躍転移例では，跳踓した リンパ節転移部より近位のリンパ節を階段状連続切片 （4 割面）により検索して転移巣のないことを確認し た.

\section{II. 成 績}

1. 直腸肛門癌におけるリンパ節跳躍転移の発生頻 度

教室の切除直腸肛門癌172例におけるリンパ節転移 陽性症例は89例（52\%）であった，占居部位別にみる と, Rs で18例中 5 例 (28\%), Ra で18例中12例 (67\%), $\mathrm{RaRb}$ で26例中16例 (62\%), $\mathrm{Rb}$ で73例中39例(53\%), $\mathrm{RbP}$ で25例中 11 例 (44\%)，P で12例中 6 例 (50\%) に リンパ節転移が認められた。これらのうち、リンパ節 跳躍転移は $\mathrm{Ra}$ で 3 例, $\mathrm{Rb}$ で 1 例, $\mathrm{P}$ で 2 例に認めら れ全体として 6 例であり，これはリンパ節転移症例の $7 \%$ \%占めていた（表 1 ）。

2. リンパ節跳躍転移症例の臨床病理学的所見

リンパ節跳躍転移を示した症例の組織型は，高分 化型腺癌が 3 例, 中分化型腺癌が 1 例, 中分化型扁平 上皮癌 (肛門癌) が 2 例であり, 組織型に特別の傾向

表 1 直腸肛門癌に持けるリンパ節転移の発生頻度

\begin{tabular}{c|c|rl|ll}
\hline 占居部位 & 切除症例 & \multicolumn{3}{|c|}{ シンパ節転移例 } & \multicolumn{2}{|c}{ 跳躍転移例 } \\
\hline $\mathrm{Rs}$ & 18 & 5 & $(28 \%)$ & & \\
\hline $\mathrm{Ra}$ & 18 & 12 & $(67 \%)$ & 3 & $(25 \%)$ \\
\hline $\mathrm{RaRb}$ & 26 & 16 & $(62 \%)$ & & \\
\hline $\mathrm{Rb}$ & 73 & 39 & $(53 \%)$ & 1 & $(3 \%)$ \\
\hline $\mathrm{RbP}$ & 25 & 11 & $(44 \%)$ & & \\
\hline $\mathrm{P}$ & 12 & 6 & $(50 \%)$ & 2 & $(33 \%)$ \\
\hline 計 & 172 例 & \multicolumn{2}{|c|}{89 例 } & $(52 \%)$ & \multicolumn{2}{|c|}{6 例 ( } & $(7 \%)$ \\
\hline
\end{tabular}

(S. 47. 12. S. 60.12. 単発癌症例)
は認められなかった。壁深達度では a2が 3 例, ss が 2 例, pm が 1 例であり, sm 拉よび ai は認められなかっ た. 脈管浸襲ではリンパ管侵襲あるいは静脈侵襲が全 例に認められた、リンパ節転移については, 症例 1 , $2 ， 3$ における原発巣の占居部位はとむにRaであり， 転移リンパ節は症例 1 で上直腸リンパ節 (No. 252) に 1 個，症例 2 で $\mathrm{S}$ 状結腸中間リンパ節 (No. 242-2)に 2 個，症例 3 で $\mathrm{S}$ 状結腸中間リンパ節 (No. 242-2)の

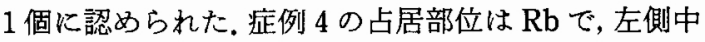
直腸リンパ節 $(N o .261 \mathrm{~L})$ と左側鼠径リンパ節（No. 292 L)にそれぞれ1個の転移が認められた。 また症例 $5 ， 6$ の占居部位はともに $\mathrm{P} て ゙ あ り$, 転移リンパ節は 症例 5 で上面腸リンパ節 (No. 252)に 1 個, 症例 6 で 左側鼠径リンパ節 (No. 292 L) の 1 個に認められた. これらの跳躍転移形式は，第 1 群リンパ節より第 4 群 リンパ節へ跳踓した症例が 1 例であり，ほかの 5 例は 第 1 群リンパ節を素通りし，直接第 2 群リンパ節への 跳躍転移形式を示していた，跳躍転移の転移方向は， $\mathrm{Ra}$ の 3 例はすべて上方向転移であり, $\mathrm{Rb}$ の 1 例は下 方向転移であった。 そしてPの 2 例は上方向転移が 1 例，下方向転移が 1 例であった。すなおち，上方向転 移が 4 例と下方向転移が 2 例にみられたが，側方向に おけるリンパ節跳踓転移は認められなかった。治療に ついては，1例は相対的非治編手術に終っていたが， ほかの 5 例はすべて治癒手術がなされていた，各症例 の予後は, 症例 6 が術後 3 年 6 力月で遠隔転移再発の ため死亡して招り，また症例 5 が術後 5 年11カ月で他 病死しているが， ほかの 4 例は現在生存中であり，予 後は必ずしも不良ではなかった（表 2 ）.

3. リンパ節跳躍転移の発生状況

リンパ節跳躍転移形式として，第 1 群リンパ節を素 通りして，直接第 2 群リンパ節へ跳躍する形式 $(\mathrm{n}(-)$

表 2 直腸肛門癌にお汸りリンパ節跳躍転移症例

\begin{tabular}{|c|c|c|c|c|c|c|c|c|c|}
\hline 症例 & $\begin{array}{l}\text { 年龄. } \\
\text { 性別 }\end{array}$ & 部位 & 組織型 & 深達度 & 脈管侵蛟 & 跳躍転移形式 & 転移リンパ節 & 郭清度 & 予 \\
\hline 1 & $53 /$ 女 & $\mathrm{Ra}$ & 高・腺癌 & ss & $\mathrm{ly}+, \mathrm{v} 0$ & $\mathrm{n}($ ( ) $\rightarrow \mathrm{n} 2$ (上方) & (No. 252) 1 個 & R3 & 12 年生存中 \\
\hline 2 & 82 /男 & $\mathrm{Ra}$ & 高・腺癌 & a2 & ly $0, v+$ & $\mathrm{n}($ ( ) $\rightarrow \mathrm{n} 2$ (上方) & (No. 242-2) 2 個 & $\mathrm{R} 2$ & 3 年生存中 \\
\hline 3 & $68 /$ 女 & $\mathrm{Ra}$ & 中・腺癌 & ss & $\mathrm{ly}+, \mathrm{v} 0$ & $\mathrm{n}($ ( ) $\rightarrow \mathrm{n} 2$ (上方) & (No. 242-2) 1 個 & R3 & 1 年 6 力月生存中 \\
\hline 4 & $43 /$ 女 & $\mathbf{R b}$ & 高・腺癌 & $\mathrm{pm}$ & $\mathrm{ly}+, \mathrm{v} 0$ & $\mathrm{n} 1 \rightarrow \mathrm{n} 4$ (下方 $)$ & (No. 261L, 292L) 1 個 & R3 & 1 年 6 力月生存中 \\
\hline 5 & $52 /$ 女 & $\mathrm{P}$ & 中・扁上癌 & a2 & $\mathrm{ly}+, \mathrm{v} 0$ & $\mathrm{n}($ 一) $\rightarrow \mathrm{n} 2$ (上方) & (No. 252) 1 個 & $\mathrm{R} 2$ & 5 年11力月他病死 \\
\hline 6 & 69／男 & $\mathrm{P}$ & 中・扁上癌 & a2 & $\mathrm{ly}+, \mathrm{v} 0$ & $\mathrm{n}(-) \rightarrow \mathrm{n} 2$ (下方) & (No. 292L) 1 個 & $\mathrm{R} 2$ & 3 年 6 力月癌死(遠隔転移) \\
\hline
\end{tabular}

(S. 47. 12. S 60.12 .) 
図 1 症例 3 ：郭清リンパ節と転移リンパ節

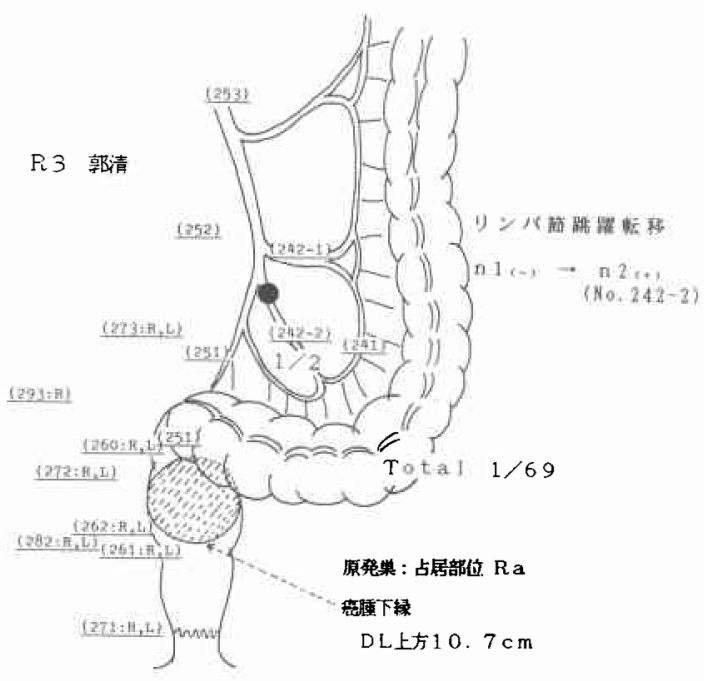

$\left.\rightarrow \mathrm{n}_{2}(+)\right)$ と，第 1 群リンパ節から第 4 群リンパ節へ 跳躍する形式 $\left(\mathrm{n}_{1}(+) \rightarrow \mathrm{n}_{4}(+)\right)$ が認められた。前 者の代表的症例と後者の 1 例のリンパ節転移状況は以 下のと拈りであった。

症例 $3\left(\mathrm{n}(-) \rightarrow \mathrm{n}_{2}(+)\right) ; 68$ 歳, 女性 血便を主訴に当科を受診し，直腸癌（Ra）の診断に て根治手術を施行した。第 3 群リンパ節までの郭清 $\left(\mathbf{R}_{3}\right)$ を行い, 69個の郭清リンパ節のうち S 状結腸中間 リンパ節 (No. 242-2)の 1 個のみに転移を認めた。す なわち，第 1 群リンパ節を素通りし，上万向の第 2 群 リンパ節への跳躍転移が認められた（図 1).同様に, 直接第 2 群リンパ節へ跳躍した症例 $(1 ， 2 ， 5 ， 6)$ は, 全郭清リンパ節のうち第 2 群リンパ節に 1 ないし 2 個の転移がみられたのみであった。

症例 $4\left(\mathrm{n}_{1}(+) \rightarrow \mathrm{n}_{4}(+)\right) ; 43$ 歳, 女性

粘血便を主訴に当科を受診し, 直腸癌 $(\mathrm{Rb})$ と診断 した，その際，左鼠径リンパ節を触知した。術前の血 清 CEA, $\alpha$-fetoprotein は正常範囲内であり, 肝転移は 認められなかった。手術は根治を目的に腹会陰式直腸 切断術を行い, 第 3 群リンパ節までの郭清 $\left(\mathrm{R}_{3}\right)$ と左 鼠径リンパ節の郭清を行った。腫瘍は長径 $6 \mathrm{~cm}, \mathrm{O}^{\circ}$ から $6^{0}$ の左側半周を占める限局潰瘍型の高分化型腺癌で

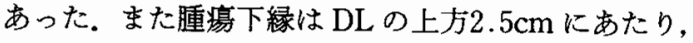
壁深達度は pm で, リンパ管侵襲が認められた。64個の 郭清リンパ節のうち, 左側中直腸リンパ節（No. 261 L）に 1 個，および左側鼠径リンパ節（No. 292L）に 1 個の転移が認められた。すなわち，側方向の第 1 群
図 2 症例 4 ：郭清リンパ節と転移リンパ節

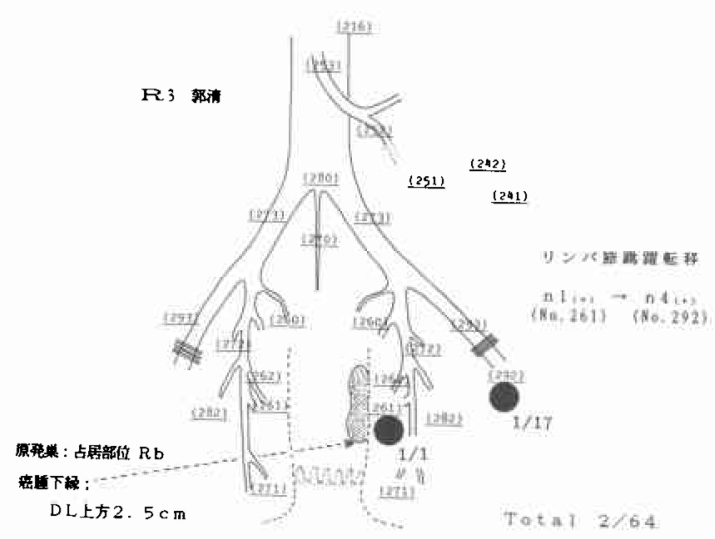

リンパ節から, 下方向の第 4 群リンパ節への跳踓転移 が認められた（図 2 ）。また本症例は，腫瘍下縁が DL の上方 $2.5 \mathrm{~cm}$ にあるにもかかわらず，鼠径リンパ節人 転移がみられた非常にまれな症例であった。第 4 群り ンパ節転移陽性のため，手術は相対的非治癒切除とな り, 術後補助化学療法として, $\operatorname{MMC}(4 \mathrm{mg} \times 10)$ 打よ び $\mathrm{HCFU}(600 \mathrm{mg} /$ 連日)を投与した。術後 1 年 6 力月 後の現在も再発の兆候なく生存中である。

\section{III. 考 察}

消化器癌のリンパ節転移の 1 つの特殊型として, 取 り扱い規約によるリンパ節分類の順序とは異なった， いわゆる跳躍転移があげられる。とくに胸部食道癌の リンパ節転移では比較的高頻度に跳踓転移が存在する と報告されている3). 直腸癌の場合にも同様の転移様 式が存在することが一部の報告者によって指摘され， たとえば直腸癌の上方向リンパ節転移において下腸間 膜リンパ節 (No. 253) のみへの転移を認めた症例が報 告されている(4)5). 土屋6), 大見ら ${ }^{7)}$ は同じく上方向リン パ節転移例に颃いて，跳踓転移が $10 \%$ にみらたと報 告し，リンパ流の短絡経路の存在を想定している。 た田中ら ${ }^{8)}$ は上部直腸癌( $\mathrm{Ra}$ )で, 旁直腸リンパ節 (No. 251）から正中仙骨リンパ節（No. 270） 八跳躍転移し た症例を示し， $\mathrm{s}$ 状結腸間膜の脈管系に沿った経路以 外のリンパ流が癒着により生じた可能性を推測してい る. 竹村ら 9 はリンフォシンチグラフィーによる下部 直腸リンパ流の検討を行い, 旁直腸リンパ節を素通り しそれょり中权側の上方向括よび側方向リンパ節に 強い集積を示寸跳躍的集積が25\%の症例にみられたこ とを示している。われわれは切除直腸肛門癌のリンパ 節転移症例 89 例の検討で， 6 例（7\%）の跳躍転移例 
を認めた。 6 例中 5 例が直接第 2 群リンパ節への跳躍 形式をとっでり，上方向転移が 4 例ならびに下方向 転移が 1 例に認められた。これらの症例ではリンパ流 の短絡が想定され，また各方向への跳躍転移の可能性 を示唆している。

直腸癌の転移リンパ節数について, Dukes ${ }^{10)}$ は治痛 切除例のリンパ節転移例のうち58.9\%が 1 ないし 2 個 の転移個数であったと述べ, Gabriel ${ }^{4)}$ や大見 ${ }^{51}$ は 3 個 までの転移がそれぞれ $50 \%, 51.7 \%$ あったと報告し， リンパ節転移の数はかなりゆっくり増加することを指 摘している，われわれの経験した跳躍転移例でも，転 移リンパ節数は 1 ないし 2 個認めるのみであり, リン パ節転移数における特徵はないるのと思われた。リン 饰節転移を組織学的に検索する際に，一般的には最大 割面のみにより判定しているが，微小転移に対してす べて検索しえているとはいえない. Kingsley ら ${ }^{111}$ は乳 癌100例に招いて，1 割面により転移陰性と診断された リンパ節に 2 割面を加えた検索を行い，2 例の転移例 をみいだしている，われわれは跳踓転移の false positiveをなくすため，跳躍転移リンパ節より近位のリン パ節を 4 割面の検索により確認した。その結果，1 割 面による検討では89例中 7 例にリンパ節跳踓転移がみ いだされたが，そのうち 1 例は 4 割面の検索より跳躍 転移と思われたりンパ節より近位のリンパ節の 1 個に 微小転移が確認され，リンパ節跳踓転移例から除外さ れた。 また, false negative の確認には全郭清リンパ節 の多数割面による検索が必要であろう。したがって， われわれの示した直腸肛門癌に括ける跳躍転移率 (7\%)は，微小転移の見逃しにより高くなっている可 能性は少なく，むしろ全郭清りンパ節の多数割面の検 索により上昇する可能性があるものと思われる。

われわれの経験した跳躍転移症例のらち, 症例 4 は 第 1 群リンパ節より第 4 群リンパ節へ跳躍する形式を 示しており，また腫瘍下縁が $\mathrm{DL}$ 上方 $2.5 \mathrm{~cm}$ にあるに もかかわらず，手術時に鼠径リンパ節転移が確認され た症例である．肛門癌では鼠径リンパ節転移が比較的 高率にみられ，その頻度は10４0\%の転移率といわれ ている ${ }^{12)}$.しかし，直腸癌では鼠径リンハ節転移をさた すことは非常にまれであり，大見7)，広瀬(3)，高橋ら ${ }^{14)}$ は治瘾切除直腸癌に颃いて, 癌が DL に接していると きのみ鼠径リンバ節転移がみられると報告している。

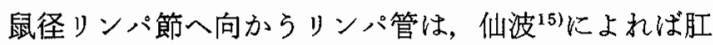
門管皮膚帯，Blair ${ }^{16)}$ によれば mucocutaneous junction 以下の perineal region から出発し, 坐骨直腸窩の

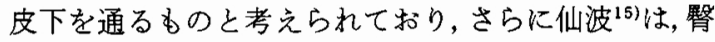
部から大腿外側を通過し鼠径リンパ節へ向から経路の 存在することも明らかにしている。これらの流域のみ ならず, 高橋ら ${ }^{14)}$ は臨床的検討より, 直腸肛門管周用を とりまく泌尿器, 生殖器を介しての経路, 側方向リン パ節を介しての逆行性経路，打よび再発巣からの経路 の存在を報告している．また直腸肛門管の壁内リンパ 管については，DLを境として上下のリンパ管に連絡 があるとするもの ${ }^{15)}$ ないとするもの ${ }^{16)}$ と研究者に よって異なっている.しかし, 黄可 ${ }^{17}$ は組織学的検討に より，直腸の粘膜下組織を走るリンパ管はその弁の方 向からみてすべて上行性であり，この上行性の弁は mucocutaneous junctionより下方 $2 \mathrm{~mm}$ までの粘膜下 リンパ管にみられたと報告している，われわれの経験 した症例 4 に括ける鼠径リン八゚節への転移形式につい ては，側方リンパ節にリンパ流を閉塞するような転移 がないことより逆行性進展は考えにくく，また腫瘍下 縁が DL 上方 $2.5 \mathrm{~cm}$ と高位に存在するため，肛門管皮 首帯を通じた経路の可能性も乏しいように思われる。 そこで本症例は $\mathrm{pm}$ 癌であるが，腫瘍の壁在性が0范 ら6゚を占める左側半周性のものであることより，腫煌 近傍転移リンパ節 (No. $261 \mathrm{~L}$ ) から直腸前方葴器を介 した左側鼠径リンパ節への跳踓転移経路，あるいは他 の短絡路の存在が想定される。

\section{結語}

1. 過去14年間に扔いて教室で切除を行った直腸肛 門癌は172例であり, リンパ節転移陽性症例は89例 (52\%)であった。これらのうち，リンパ節跳踓転移は $\mathrm{Ra}$ で 3 例， $\mathrm{Rb}$ で 1 例，Pで 2 例に認められ，リンパ 節転移症例の $7 \%$ （6/89例）を占めていた。

2. リンパ節跳躍転移形式として, 第 1 群リンパ節を 素通りして直接第 2 群リンパ節へ跳躍する形式が 5 例 に認められた。 また，腫痬下縁が DL 上方 $2.5 \mathrm{~cm}$ にあ るにもかかわらず，鼠径リンパ節へ転移が認められた 直腸癌症例に㧊いて，第 1 群リンパ節から第 4 群リン パ節へ跳踓する形式が認められた。

$$
\text { 文献 }
$$

1）大腸癌研究会編：大腸癌取扱い規約. 東京, 金原出 版, 1983

2）暒谷 鐶, 広瀬益雄：直腸癌根治手術, 手術 25 $35-50,1971$

3）山崎 繁, 吉野邦英, 佐藤達夫活か：胸部食道癌跳 躍転移に括ける胸管の役割。リンパ学 7: $77-80,1984$

4) Gabriel WB, Dukes CE, Bussey H Jr: Lym- 
phatic spread in cancer of the rectum. Br J Surg $23: 395-413,1935$

5）斉藤 博：直腸癌の病像とリンパ節転移および切 除予後に関する臨床病理学的研究一第一編. 日外 会誌 $75: 701-714,1974$

6）土屋周二：直腸癌根治手術に扰けるッンパ節郭清 術. 日外会誌 $80 ： 1520-1523 ， 1979$

7）大見良裕：直腸癌のリンパ節転移の特徵一拡大郭 清による摘出りンパ節の検討一. 日外会誌 81 ： $676-687,1980$

8）田中猛夫, 西村一郎, 松下利雄法か: S 状結晹癌. 直腸癌のリツパ節転移. 非定型的転移症例の検討. 日消外会誌 $14: 1491-1494 ， 1981$

9）竹村克二, 安藤昌之, 岡部 聡住か：下部直腸リン 八流。 日本大腸肛門病会誌 $39: 113-120,1986$

10) Dukes CE: Cancer of the rectum. - An analysis of 1,000 cases-. J Pathol 1:527-539, 1940

11) Kingsley WB, Peters GN, Cheek JH: What constitutes adequate study of axillary lymph node in breast cancer?. Ann Surg 201: $311-314,1984$

12）山本恵一, 龍村俊樹, 関 雅博はか：肛門䆆. 消外 $6: 171-181,1983$

13）厇瀬益雄, 山田 肃, 暒谷 鐶：直腸癌根治手術に おけるリンパ節転移の態様および壁深達度につい て。癌の臨 $17: 254-260,1971$

14）高橋 孝, 古島 葶, 太田博俊はか: 肛門癌のリン パ節転移の特徵一とくに鼠径リンパ節転移につい て一. 日本大腸肛門病会誌 $34: 473-478,1981$

15）仙波嘉清：直腸淋巴管系統に関する解剖学的研 究. 福岡医大誌 $20 ： 1213-1268,1927$

16) Blair JB, Holyoke EA, Best RR: A note on the lymphatics of the middle and lower rectum and anus. Anat Record $108: 635-644,1950$

17）黄可富彦：直腸肛門管の壁内リンバ管の細分布 そついて。 日本大腸肛門病会誌 $29: 548-569$, 1976 